\title{
Apply Remote Sensing to Monitoring Dynamics of Built Environment in The Core Area and The Border of Solok City
}

\author{
Silvia Evandi, Ernawati \\ Department of Geography, State University of Padang \\ Correspondence author geo.silvi.20@gmail.com
}

\begin{abstract}
The development of unmanned satellite space technology is increasingly willing, the emergence of medium resolution satellites with sensitivity and spectral variants such as Landsat is very effective in observing environmental changes, while the purpose of this study is to monitor the development of builtin land using image transformation techniques, estimating built-in land changes. The research method uses the NDVI image transformation technique, NDBI and Built Up Index, with Landsat satellite image data obtained from USGS. Accuracy sampling is done by purposive sampling with confusion matrix accuracy test technique. The research results were found. developed land for the period $2004-2010$ with a percentage of $19.25 \%$, for stages $2010-2018$ with a percentage of $30.25 \%$. The land development was built based on the area of the highest sub-district in the Kubung area in the early period with a percentage of $7.20 \%$ then in the second period with a percentage of $32.23 \%$. The quality of the accuracy of the results of image analysis using confusion matrix technique with an image accuracy level in a field sample of 185 with an image accuracy of $86.04 \%$.
\end{abstract}

Keywords: Built environment, image analysis, remote sensing

\section{Introduction}

Urban area is an area that has the dominance of built land which tends to be high with the condition of the distance between buildings that are close to one another, related to the increasing number of population and the increasing activity of the population in a place, it will have an impact on increasing cover. land, especially built-up land, which is increasing to meet the needs of housing in urban areas, so this shows that cities have a high attractiveness for residents around them. The impact of population growth on the increase in primary needs on the development of developed land is the reduction of agricultural land, because agricultural land is converted into built-up land, for example for settlements, roads, markets etc [1].

The impact of the growth of developed land, which is a problem that is quite difficult to overcome by urban development, besides having a positive impact on the welfare of residents, cities also have negative impacts on several environmental aspects. Initially, most of the urban land was agricultural land or green open space [2] but there was an increase in the need for space to accommodate residents and activities, the land used by residents for farming or green open space tended to experience uncontrolled conversion of land into built-up land. The development of developed land has a major influence on the environment and the ecosystem around it [3]. The physical development and growth of the city is very dynamic, making the city require regular monitoring or monitoring of land changes so that they can know the development of the city. One of the reasons for the development of developed land is the expansion process, the expansion process itself can be interpreted as a process of changing non-built land cover into built-up land [4].

The use of remote sensing technology is very rapid in various fields, including in vegetation studies, environmental observation, land use, agriculture, forestry, geology, urban studies, climate change and biodiversity conservation. Furthermore, many remote sensing algorithms have been developed according to the needs of each data user [5][6]. Remote sensing has also been divided into various interpretation techniques, both in image classification models and image transformation [7][8]. The importance of remote sensing in area-built land monitoring studies, because remote sensing is able to collect information about objects and their environment remotely without physical touch [9][10]. Based on the problem of uncontrolled constructed land changes that result in damage to biological ecosystems, resulting in various problems with other undeveloped land. Based on the existing problems, the researcher is interested in examining several parts of the problem regarding, monitoring the built area. 


\section{Material and Method}

\subsection{Data and tools}

E used several data and tools to processing and analysis data, which detail information about data has used in table 1 and 2.

Table 1. Data

\begin{tabular}{lll}
\hline No & Data & Sources \\
\hline 1 & Landsat TM5 & http://landsat.usgs.gov \\
2 & Landsat OLI 8 & http://landsat.usgs.gov \\
3 & Administration Map & http://tanahairindonesia.go.id \\
\hline & & Table. 2 Tools \\
No & Tools & \\
\hline 1 & ENVI & \\
2 & Q-GIS & \\
\hline
\end{tabular}

\subsection{Analysis Data}

\section{Transformation of Built Environment Image}

In this research, several analysis processes were carried out. Image transformation models that are effective for distinguishing building materials from natural materials usually utilize near, middle and far infrared channels, considering that this spectral region is known to be sensitive to differences [11][12]. The image transformation used is NDVI, NDVI to obtain the final result in the Built-up Index transformation.

$$
\begin{aligned}
& \text { NDVI }=\text { Near infrared }- \text { red } / \text { Near infrared }+ \text { red } \\
& \text { NDBI = Middle infrared }- \text { Near infrared } / \text { Middle infrared }+ \text { Near infrared } \\
& \text { Built-Up Area Index }=\text { NDBI- NDVI }
\end{aligned}
$$

\section{Accuracy Assessment}

In the accuracy test technique, the first thing to do is determine the number of samples to be used in image data analysis with field conditions, then the determination of the number of samples for accuracy is as follows [9]:

$$
N=Z^{2}(P)(q) / E^{2}
$$

Where:

$$
\begin{aligned}
& N=\text { total pixel } \\
& \left.Z^{2}=2 \text { (The normal standard deviates for the level of confidence } 90 \%\right) . \\
& P=\text { expected accuracy } 90 \% . \\
& q=100-90 . \\
& E^{2}=\text { is an allowable error } 5 \%
\end{aligned}
$$

The process of assessing the accuracy of the analysis results by assessing the accuracy of the data with data that has been collected in the field using the Confusion Matrix technique [13] where:

$$
M A=X \text { cr pixel) } / X \text { cr pixel }+ \text { Xo pixel }+ \text { Xco pixel) } \times 100 \%
$$

$M A=$ Mapping Accuracy

$X c r=$ total class $\mathrm{X}$ corected

$X o=$ total class $\mathrm{X}$ who entered another class (omisi)

$X c o=$ Total class $\mathrm{X}$ addition to the class lain (comisi) 


\section{Results and Discussion}

From the image transformation model, the initial output is in the form of a gray scale image or an image that is gray in color. The built-up land cover is classified as Built Up Area, where the transformation of the built up area shows the proportion of the built-up land more clearly then a guided classification is carried out from the grey scale image interpretation of the Built Up Area index.

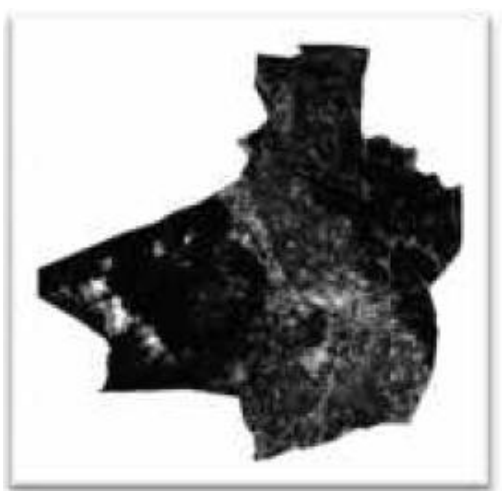

NDVI 2004

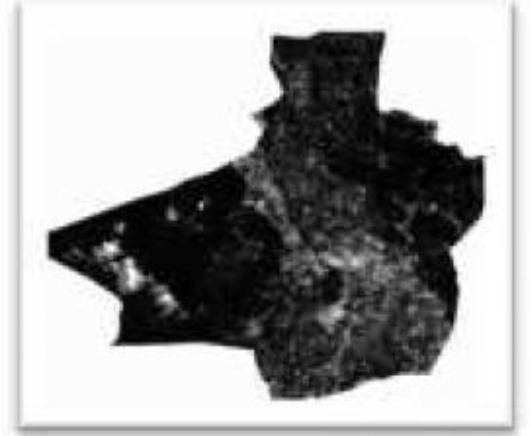

NDVI 2010

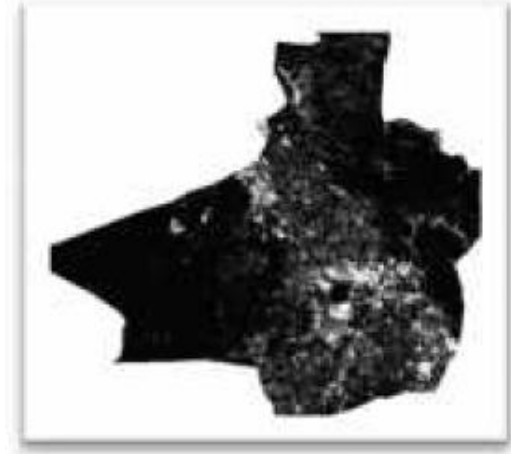

NDVI 2018

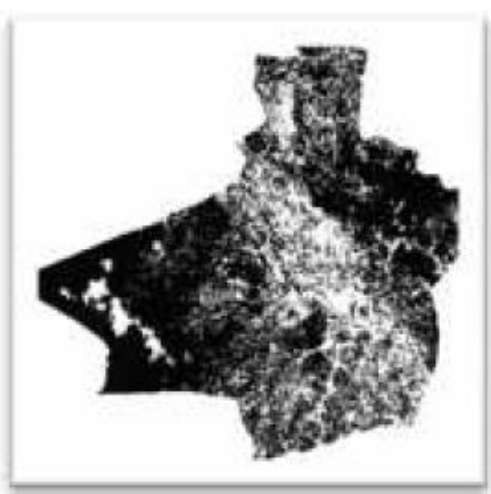

| NDBI 2004

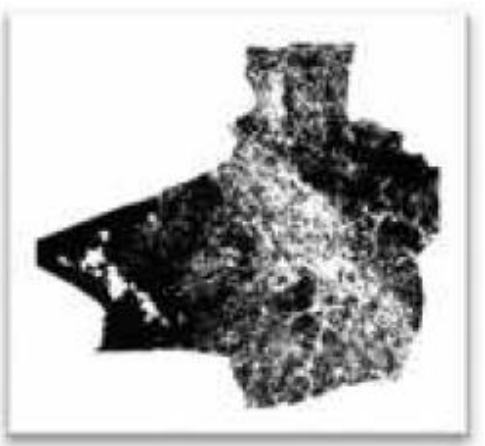

| NDBI 2010

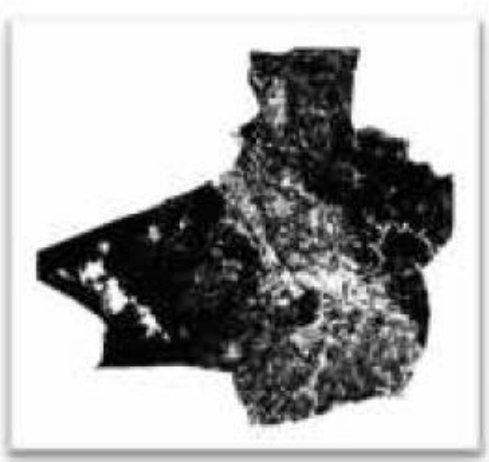

| NDBI 2018
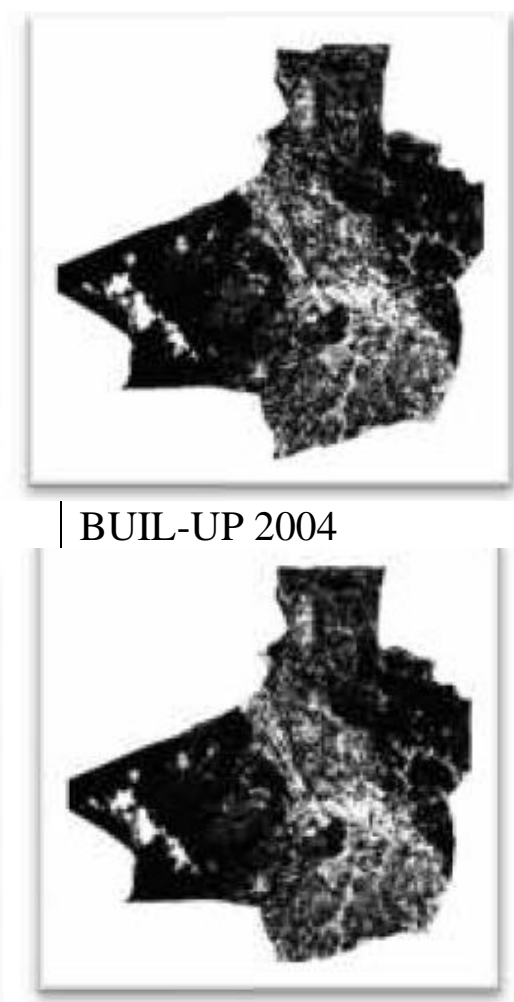

| BUIL-UP 2010

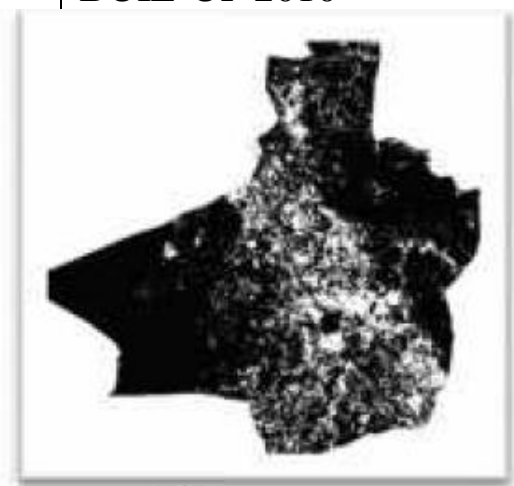

BUIL-UP 2020

Figure 1. Compare among NDVI, NDBI, Built-up

In an image object, the energy that radiates a lot will appear bright, and a little emitting appears a little dark [14]. The contrast of the appearance of the built-in land in a single image, each image transformation will then be grouped into two classes, namely built and non-built land, with the result that the level of quality of land development is built with a higher contrast, which is a level that has a large area each year. If the land is built with vegetation contrast, objects in the field can be found in the form, large open land, in the non-built category.

From the picture above, it is clear that NDVI emphasizes the aspect of vegetation, NDBI emphasizes the built-up land aspect, but the appearance between built and non-built land lacks contrast in the 
research location. The phenomenon of the urban environment, which is usually dominated, can be seen from the buildings and structures[13]. The actual building conditions do not always differ in their environmental environment, especially around land or open land [14]. Then the next step is perfected with the Built-up Index transformation, which is able to attenuate the appearance of objects and discriminate non-constructed land objects, so that the quality of the results of data analysis is sharper [12]. The changes to highlight the correlation aspect of built-up land, especially for the expansion of the near infrared and red channels, besides that the pen can also suppress the shadow effect on the built-up land.
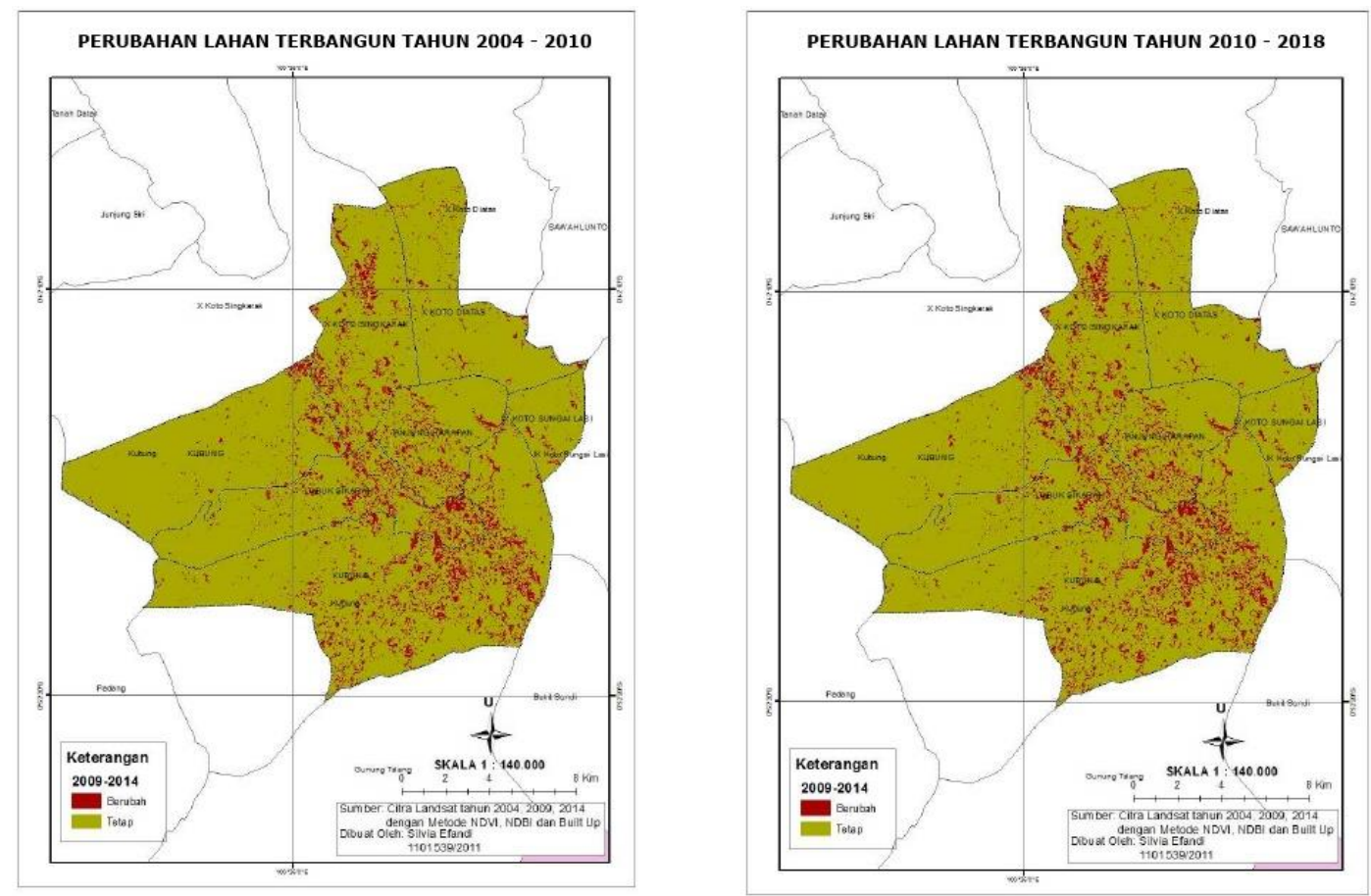

Figure 2. Comparison about built environment

For more detail, the dynamics of the development of the built environment at the research location are extracted and divided based on the area of administration, and are presented in table No.1 below:

Table 3. Dynamics of built environment development

\begin{tabular}{lllll}
\hline No & District & \multicolumn{2}{c}{ Year } \\
\cline { 3 - 5 } & & $\mathbf{2 0 0 4}$ & $\mathbf{2 0 1 0}$ & $\mathbf{2 0 1 8}$ \\
\hline 1 & IX Koto Sungai Lasi & 21.33 & 32.49 & 47.25 \\
2 & Kubung & 661.71 & 713.11 & 1359.03 \\
3 & X Koto Diatas & 46.96 & 80.64 & 60.83 \\
4 & X Koto Singkarak & 217.06 & 303.02 & 342.28 \\
5 & Lubuk Sikarah & 344.13 & 441.22 & 575.49 \\
6 & Tanjung Harapan & 283.43 & 379.64 & 411.06 \\
\hline
\end{tabular}

Overall, the increase in land being built from year to year follows the dynamics of human activities in infrastructure and settlement development. Based on the results of the analysis of land changes built by NDVI, NDBI and Built Up Area 2004 to 2018, the built-up land category occurred. Land changes built in the research year can be seen from the map of the development of the developed land in the sub-district area, it can be concluded that there have been changes in the built-in land from 2004, 2010 and 2018 which are quite developed and look very different. Based on the results of image analysis, the area of the built-in land area from 2004 which ranges from $1574.66 \mathrm{Ha}$, and in 2010 which ranges from $2718.34 \mathrm{Ha}$ and from 2018 which ranges from $4299.97 \mathrm{Ha}$, there is an increase in the area of 
built land. Land changes were built based on the village with a land area in 2004 with a range of $1574.79 \mathrm{Ha}$ and in 2010 with a range of $2718.68 \mathrm{Ha}$ then in 2018 with a range of $4299.849 \mathrm{Ha}$. The development of residential land is not only centered on urban areas but also in hinterland areas where this area is mostly dominated by agricultural areas [17][18]. The change of land cover into settlement area is generally caused by many factors, such as because nature or intrinsic of land resources, in accordance with the principle of supply-demand economy law experiencing the scarcity structure as a result of increasing demand for land for the purpose settlement area that contribute to encouraging the conversion of non-forest land use, and government policies that provide big investment opportunities for, nevertheless investment rates in the industrial and mining sectors are still not followed by the rate of legislation stipulation and legislation which can be used as a reference in controlling land cover changes [19][20].

Table 4. Result of accuracy assessment

\begin{tabular}{lllll} 
& & \multicolumn{2}{l}{ Total } \\
\cline { 3 - 4 } & & Bield sample data & \\
\hline Output & Built-up & 118 & Non Built-up & 129 \\
classification & Non Built-up & 8 & 67 & 75 \\
& Total & 126 & 78 & 204 \\
\hline
\end{tabular}

Accuracy: $185 /(185+15+15) * 100 \%=86,04 \%$

The following results of the built-in land development accuracy test, the analysis error was found in the $86.04 \%$ accuracy test, from this accuracy test, 19 samples of the built-in land contrast level were obtained where the difference in the accuracy of the image contained built-in land errors. Error analysis in the accuracy image can be found an error in the built category with an error rate of 11 samples into another class and in non-built samples there is an error value of 8 samples. This difference in accuracy shows the difference in the accuracy of the data analyzed in field research, by obtaining different levels of confidence. The distribution of field samples, so the conclusion on the error rate in the samples in the field with the classification of image accuracy is $81.33 \%$.

\section{Conclusion}

From the results of monitoring the development of built-in land using image transformation techniques, it is clear that the Built-up Index model is very effective in perfecting NDBI transformation. The results of this analysis are able to better discriminate against non-built objects. Developed develop land spreads not only in the core urban area, but also develops in neighboring urban areas, or hinterlands. The quality of the accuracy of this analysis result is quite good.

\section{Reference}

[1] Yunus, H. S. (2005). Manajemen Kota Perspektif Spasial. Yogyakarta: Pustaka Pelajar.

[2] Wilis, Ratna, et.al. (2020). Evaluation of Carrying Capacity Lands for Food Agriculture Based on Land Degradation in Pagar Alam City - Indonesia. International Journal of Management and Humanities (IJMH) ISSN: 2394-0913, Volume-4 Issue-9, May 2020.

[3] Rahman, et.al (2020). Spatial Assessment of Landscape Structure Changes and Ecological Connectivity in Pariaman. Journal of Remote Sensing GIS and Technology. Vol 6 Issu 2. May.

[4] Suharyadi (2010). Interprestasi Hibrida Citra Satelit Resolusi Spasial Menengah Untuk Kajian Densifikasi Bangunan Daerah Perkotaan Di Daerah Perkotaan Yogyakarta. (Ringkasan Distertasi). Yogyakarta :Fakultas Geografi UGM.

[5] Cambell, J. B and R.H. Wynee. (2011). Introduction to Remote Sensing, Fifth Edition. New York: Guildford Press. ISBN 978-1-60918-176-5.

[6] Hidayat R A (2020). Spatial Modeling of The Threat of Damage to The Peatland Ecosystem In The Mainland of Bengkalis Regency, Riau Province. Journal Social Polites. Vol 20. Special Issue. No 2. doi: 10.33541/sp.v21i3.2249 
[7] Hanif M, Nofrizal AY (2017). Hubungan Perkembangan Lahan Terbangun Perkotaan Dengan Fenomena Iklim Mikro Urban Heat Island. Jurnal Spasial, Volume 3, Nomor 4, 2017: 23-29. Padang. Program Studi Pendidikan Geografi STKIP PGRI Sumatera Barat.

[8] Hanif M, et.al (2019). Multi Spectral Satellite Data to Investigate Land Expansion and Related to Micro Climate Change as Threat to The Environment. Journal IOP Conf. Series: Earth and Environmental Science. Volume. 303. doi: 10.1088/1755-1315/303/1/012030.

[9] Mc Coy M. Roger. (2005). Field Method in Remote Sensing. The Guildford Press: New York London.

[10] Hanif, et.al (2017). Investigation Character of Natural Forest Ecosystem, Use High Resolution and LiDAR Data. Journal of Environment and earth Science (IISTE). 2224-3216 (paper) 22250948 (Online). Volume 7, Nomor 10, hal 138-145.

[11] Danoedoro, Projo. (2012) Pengantar Penginderaan Jauh Digital. Yogyakarta: CV Andi Offset.

[12] Danedoro Projo. (2008) Sains Informasi Geografis: Kedudukan, Perkembangan dan Kontribusinya dalam Ilmu Geografi. Yogyakarta: Fakultas Geografi.

[13] Purwadhi, dkk. (2008). Pengantar Interpresasi Citra Penginderaan Jauh. Semarang: Geografi FIS UNNES

[14] Handayani Dewi, et.al. (2005). Pemanfaatan Analisis Spasial Untuk Pengolahan Data Spasial Sistem Informasi Geografi. Universitas Stikubank Semarang. Jurnal. Teknologi Informasi Dinamik. Vol X. ISSN: 0854-9524.

[15] Lillesand, Kiefer. (1994). Penginderaan Jauh dan Interprestasi Citra. Yogyakarta: UGM Press.

[16] Hanif M (2017). Application Multi Vegetation Index to Mapping Mangroves Distribution Coastal Environment Northeast Province of Aceh. Sumatera Journal Disaster Geography and Geography Education. SJDGGE, Vol 1. No.1

[17] Wilis Ratna et.al. 2020. Characteristic Outdoor Thermal Comfort Index (OCTI) At Mandeh Tourism Site. International Journal Geomate 19 (73), 250-256

[18] Hermon Dedi. 2014. Impacts of Land Cover Change on Climate Trend in Padang Indonesia. Indonesian Journal of Geography. Fakultas Geografi Universitas Gajah Mada.

[19] Hermon Dedi, et.al. (2017) The Model of Land Cover Change into Settlement Area and Tin Mining and its Affecting Factors in Belitung Island, Indonesia. Journal of Environment and Earth Science. IISTE.

[20] Hermon Dedi. (2016).' Climate Change Mitigation'. Raja Grafindo Persada. Jakarta (in Indonesian). 